\title{
The Case for an Aviation English Screening Tool for US Flight Schools
}

Argumentos em favor de um teste seletivo de inglês para aviação para os centros de formação de pilotos nos EUA

\author{
Jena LYNCH (ERAU) ${ }^{1}$ \\ Adriana Mendes PORCELLATO (USP) ${ }^{2}$
}

\begin{abstract}
This article makes the case for an aviation English test which screens and assesses incoming non-native English-speaking flight students to US flight training organizations. The need for such a test arises from the lack of standardization in flight students' aviation English proficiency assessments throughout their flight training and the potential negative consequences of inadequate proficiency for students, training centers, and other stakeholders. Looking into proficiency tests that are used as screening measures in other domains, it becomes clear that an adequate screening test for flight training candidates is needed. An existing proficiency test specifically designed for flight and ATC training candidates is also discussed. Results of this investigation point to two main conclusions: first, there is a need for a deeper understanding of the flight training domain through observation, collection and analysis of written and spoken texts in a variety of genres and registers that are typical of the flight training context; second, the necessity remains for a screening tool that takes into account the specificities of the flight training domain.
\end{abstract}

Keywords: Aviation English, Ab-initio Pilots, Flight Training, English Proficiency, Assessment

\section{RESUMO}

Este artigo argumenta a favor da implementação de um teste de inglês para aviação que avalie e selecione estudantes de aviação falantes não nativos de inglês que queiram ingressar em uma escola de aviação civil nos EUA. A necessidade por esse tipo de teste surge da falta de padronização na avaliação da proficiência em inglês para aviação dos estudantes durante seu treinamento de voo e das potenciais consequências negativas que uma proficiência inadequada pode trazer para os alunos, as escolas de aviação e as outras partes envolvidas. Ao examinar os testes de proficiência utilizados como método de seleção em outros contextos, desponta a necessidade de criar um teste próprio para candidatos à formação de pilotos. Analisa-se também um teste de proficiência criado especialmente para candidatos à formação de pilotos e controladores. Os resultados dessa investigação apontam para duas conclusões: em primeiro lugar, precisa-se alcançar um maior entendimento do contexto de treinamento dos pilotos por meio de observações, coletas e análises de dados escritos e orais nos diversos gêneros e registros que são típicos desse ambiente; em segundo lugar, permanece a necessidade de um instrumento de avaliação que leve em consideração as especificidades do contexto de treinamento dos pilotos.

\footnotetext{
${ }^{1}$ Embry-Riddle Aeronautical University Worldwide, Daytona Beach, Florida, USA. College of Aeronautics, Aviation English Specialist; ORCID: https://orcid.org/0000-0003-3563-2684; jena.lynch@erau.edu

${ }^{2}$ Universidade de São Paulo, São Paulo, SP, Brazil. Departamento de Letras Modernas (DLM); ORCID: https://orcid.org/00000001-6644-6038; adriana.porcellato@alumni.usp.br
} 
Palavras-Chave: Inglês para Aviação, Pilotos Ab Initio, Treinamento de Voo, Proficiência em Língua Inglesa, Avaliação

\section{Introduction}

There remains a need for English-proficient non-native English speaking pilots around the world. While much attention has been focused on language concerns related to operational personnel and radiotelephony (e.g., licensed pilots and air traffic controllers), far less has been given to flight students, many of whom receive their training in English-medium environments. In the United States, there are upwards of 40,000 international flight students (HOFFMAN, 2020), many of whom are non-native English speakers (NNES).

The United States Federal Aviation Administration's (FAA) Aviation English Language Standards (2017) require that flight students be English proficient, but a lack of standardization in the evaluation procedure may allow flight students to slip through the cracks with insufficient proficiency. As evidence, a recent FAA Safety Briefing article cited 60 pilot deviations since 2018 attributed to "English language and terminology issues"3 (HOFFMAN 2020). "Pilot deviation" refers to an action taken by the pilot that either does not follow instructions given by air traffic control or has violated a Federal Aviation Regulation (FAA, 2017). These deviations can have serious and even life-threatening consequences.

In the flight training context, pilot deviations are one concern among many. US flight schools employ one-to-one interaction with a flight instructor as a primary source of instruction and training for students (FAA, 2006). As a result, the role of listening and speaking skills as well as communicative competence is augmented in the success of a flight student in the US. Inadequate language skills can lead students to make slow progress (BIESWANGER; PRADO; ROBERTS, this volume). Slower progress inflates the price of their training, in turn reflecting poorly on the efficiency of the training organization.

To reduce the risk of language-related delay, frustration, or safety hazard during training, some flight training organizations have looked to general and academic English assessments. In her study of how communication is taught in collegiate flight training programs, Campbell-Laird (2006) found that TOEFL scores were being used by most organizations as "a screening device for candidates admissions to programs" (CAMPBELL-LAIRD, 2006, p. 30). However, a growing understanding of the language skills needed for efficient flight training (BIESWANGER; PRADO; ROBERTS, this volume; ROBERTS; ORR, 2020; UDELL; SCHNEIDER; KIM, forthcoming) should lead to more effective language testing

\footnotetext{
${ }^{3}$ While the article implies that these deviations were a result of limited English proficiency on the part of the NNES pilot, in a globalized world, it is unfair to put the onus of clear communication only on NNES. NES pilots and controllers also need to use standard phraseology and accommodate for NNES members of the aviation community. As stated in ICAO Document 9835, "the burden for improved communications should not be seen as falling solely on non-native speakers" (2010, p.5-4).
} 
at various points during flight training. This article advocates for the widespread use of a flight-training specific English proficiency test as a screening too ${ }^{4}$ to identify incoming candidates in US flight training organizations who may need additional language support before or during flight training.

Hence, the following sections of this paper will a) address the requirements regulating aviation English in the US context and their impact on flight training organizations, b) discuss the flight training domain, c) examine English tests that have been used to screen and assess NNES flight training candidates' proficiency, and d) outline a plan for a screening test that takes into account data from research in the flight training context.

\section{Current practice and regulations}

As an example of current practice, consider "student X", a non-native English speaker (NNES) who enters the flight training program of an aviation-focused university meeting the university's minimum English language standards (i.e., a specified TOEFL or IELTS score). Student X begins ground school classes and practical flight training during his first semester. His flight instructors begin to express concerns about student X's spoken English ability. They are frustrated by his slow interactions, difficulty communicating over the radio with air traffic control (ATC) ${ }^{5}$, and lack of ability to demonstrate that he understands key aviation concepts during oral exams and instructions in the aircraft. The student is grounded for insufficient English proficiency and referred to the local Flight Standards District Office (FSDO). At the FSDO, an Aviation Safety Inspector (ASI) requires him to seek out additional language training before being re-tested. Likely without informed guidance on selecting appropriate language training, student X may spend time and money in academic or general language programs that cannot provide the aviation-specific language skill support that he needs. Rather than continue to pay for additional language training, the student may drop out and return to his home country.

Student X's situation does not represent the only undesirable outcome. The frustration and additional costs associated with insufficient English ability are a drain on flight program resources, an expense for the student and sponsoring governments or companies, and at worst a serious safety concern. As noted by Bieswanger, Prado and Roberts (this volume), the demands of learning and verbally demonstrating the theoretical and operational knowledge required for flight training affect all flight students, but for students using English as their second language, it is an even greater challenge.

\footnotetext{
${ }^{4}$ In this article we adopt Campbell-Laird's (2006) use of screening tool to describe the use of the test and use the terms screening tool and screening test interchangeably. We conceptualize the meaning of screening test following Carr's definition: a "proficiency test used to make selection decisions" (2011, p.327).

${ }^{5}$ For the purposes of this paper, ATC will refer to air traffic controllers in general or the concept of air traffic control (such as for students of this discipline), rather than a specific person. Air traffic control officer, abbreviated as ATCO, will be used to refer to the professionals who work as air traffic controllers.
} 


\subsection{Defining aviation English for the current discussion}

The term aviation English is a central point of the current discussion and should be defined at the beginning of our discussion of practices related to testing in this area. The International Civil Aviation Organization Document 9835 uses the term "aviation language" to encompass the language used within the aviation industry for a wide variety of training and operational purposes (2010, 3-2).Under the umbrella of aviation English, a variety of smaller subsets exist, such as plain language, aeronautical radiotelephony communication, and standardized phraseology (ICAO, 2010). Tosqui-Lucks and Silva (this volume) and Roberts and Orr (2020) acknowledge that the term Aviation English is commonly, and at times confusingly, used to refer to language used in many different contexts within aviation.

Without overlooking the importance of clearer naming conventions for the subsets of aviation English, articulated by Tosqui-Lucks and Silva (this volume) as a means to more targeted teaching and testing in the global aviation community, in the current discussion, the term "aviation English" is used to cover the breadth of English used during flight training. This choice can be justified in that the English used for flight training includes both aeronautical radiotelephony communications and "other uses of English in the communication between multiple aviation professionals" (SCARAMUCCI; TOSQUI-LUCKS; DAMIÃO, 2018 p. 296-297 apud TOSQUI-LUCKS; SILVA, this volume). More illustration of the context of flight training, and thus a clearer illustration of the English used during flight training, follows later in the current discussion.

\subsection{International requirements for operational pilots and ATCOs}

The International Civil Aviation Organization (ICAO) has promoted the importance of oral English proficiency specific to aviation operations in a globalized world. In Document 9835 their Language Proficiency Requirements (LPRs) and guidance to member states on training and test harmonization shed light on the importance of English proficiency, and the need for plain language (beyond the standard phraseology) proficiency in particular (ICAO, 2010). The LPRs describe proficiency levels for professional pilots and air traffic controllers in terms of pronunciation, structure, vocabulary, fluency, comprehension, and interaction, using a scale from Pre-elementary level 1 to Expert level 6. In ICAO member states, the candidate must earn a rating at or above Operational Level 4 to be eligible for licensure but, since there is little regulation/standardization on how the tests need to be structured, we agree with Friginal et al. (2020, p. 206) that "Aviation English testing remains a widely unregulated industry". The ICAO LPRs have been widely evaluated and debated; however, for the current discussion, 
we will focus on their bearing on the United States' Federal Aviation Administration (FAA) and their limited applicability to flight training candidates ${ }^{6}$.

\subsection{The historical evolution of the US FAA Aviation English Language Standards}

Due to the relatively low cost and high availability, the United States has been a popular destination for flight training. Although students often wish to begin practical flight training as soon as possible, doing so requires students to use English in higher stress, dynamic situations in the aircraft earlier in their training. The FAA recognizes that English ability should be checked prior to any certification or rating. FAA Advisory Circular (henceforth AC) 60-28 stated broadly:

It is important that all airman applicants demonstrate their ability to read, speak, write, and understand the English language. Each applicant must demonstrate an ability to mentally grasp critical information which often must be read and understood while conducting a variety of aviation operations. (FAA, 1997, p. 2)

From the perspective of the FAA, the candidate's ability to use English to conduct aviation operations is rightly the most critical factor. However, the construct of an ability to read, speak, write, and understand English lacks specificity in skills, tasks, and minimum acceptable level. From the language assessment perspective, this description may be too broad to be useful as a construct definition for a valid test $^{7}$.

Moreover, the AC states, "the responsibility for ensuring applicants meet the English language requirements is shared by flight and ground instructors, aviation schools, designated examiners, and aviation safety inspectors" (FAA, 1997, p.2). This means the burden of language testing falls on the shoulders of aviation operations personnel, with no mention of training, norming, nor involvement of academically-qualified language testing experts.

The timing of this language proficiency evaluation is to be included with other checks for eligibility "prior to beginning the practical test or accepting an application for an airman certificate or rating" (FAA, 1997, p.2). For the purposes of this discussion, it is relevant that no certification of English proficiency is required to begin flight training. The first language evaluation would happen several weeks or months into training during the application process for a student pilot license; around the time of a student's first solo flight. The suggested test procedure in 1997 was to have the FAA examiner ask the

\footnotetext{
${ }^{6}$ We use the term flight training candidates to denote individuals who aspire to become flight students. These candidates may be in the process of applying to a flight school or may have been admitted to a program, but they have not begun training yet. They are not yet accountable for knowledge of aviation operations or aeronautical radiotelephony. The term flight student refers to an individual currently undertaking flight training who will become increasingly accountable for operational knowledge and radiotelephony proficiency over the course of their training.

${ }^{7}$ Carr defines construct as "the ability that we want to assess;" construct definition as "statement of specific aspects of language ability a construct is regarded as including;" and construct validity as "degree to which it is appropriate to interpret a test score as an indicator of the construct of interest" (CARR, 2011, p. 315)
} 
candidate to read a section from any applicable aviation manual, then summarize the section both in written and spoken English. Candidates would also be asked to role-play radiotelephony communications, including copying down information and reading it back. The FAA suggested that "the examiner will evaluate the applicant's speech and accent, if any, relative to sentence patterns, sentence structure, spelling of written text, and in the case of an air traffic control clearance, use of standard clearance terminology" (FAA, 1997, p.1), though no rubric or rating scale was provided.

A change to AC 60-28 issued in 2010 reflected ICAO's guidance that airmen be certified Englishproficient at ICAO Operational Level 4 (FAA, 2010). The 2010 AC included an Appendix of ICAO's descriptors for Operational level 4 as guidance. Even with the addition of these descriptors, Dusenbury and Bjerke (2013) noted that the AC provided limited guidance on how to conduct the evaluation, and still no guidance on screening applicants prior to flight training.

In the most recently updated AC 60-28B (2017), the FAA codified their Aviation English Language Standards (AELS). According to these standards, any person responsible for performing this evaluation should familiarize themselves with the LPRs contained in the 150-page ICAO Doc 9835 and review samples of candidates at various ICAO levels published in the ICAO Rated Speech Samples Training Aid (RSSTA) (ICAEA, 2011). Moreover, FAA evaluators are asked to prepare "multiple plans of action to conduct an AELS evaluation" to avoid test predictability (FAA, 2017, p. 5). According to the FAA AELS Appendix A the evaluator might conduct the evaluation by first interviewing the candidate using aviation content questions relevant to the license or rating being applied for. Then the evaluator could provide authentic oral input (e.g., listening to ATC) or written aviation materials. Finally, the evaluator could ask the candidate to summarize or paraphrase the information in their own words (FAA, 2017). Based on these tasks, the evaluator should then refer to the ICAO descriptors and decide "whether or not the applicant can communicate with ATC, pilots, and others involved in preparing an aircraft for flight and operating an aircraft in flight, with or without radio" (2017, p. A-2). This determination certifies whether the candidate is English proficient ${ }^{8}$.

The AELS is not a single assessment; instead, as stipulated by the FAA, English proficiency should also be continuously evaluated during any application, test, review, or check (2017, p. 4-5). Consequently, at any point in training (though notably not prior to admission) any evaluator can deem a student pilot's English proficiency insufficient, halting their progress. This continuous evaluation is an important safety measure; however, the effective implementation of this on-going assessment requires vigilance on the part

\footnotetext{
${ }^{8}$ The ICAO LPRs and descriptors are intended only for aeronautical radiotelephony communications between pilot and controller. The FAA AELS appears to apply the LPRs and descriptors more broadly to include other communication in aviation operations.
} 
of every evaluator, as well as an informed, shared understanding among evaluators of the complex interaction between language and content knowledge.

Despite ICAO Document 9835 guidance that evaluators must be "well-informed and experienced" and "agree upon standardized procedures for the implementation of the criteria" (2010, E-3), the AELS evaluation process in the US is not yet standardized, leaving it up to individual flight training organizations (FTOs) and individuals within those organizations to prepare for and carry out the assessment of their candidates’ English abilities.

Even if aviation personnel are well-studied in the entirety of ICAO Document 9835 (2010), in chapter 6 of that same document, ICAO makes clear that language testing must be led and supported by academically qualified language specialists. Without such linguistic support, therefore, those charged with implementing the AELS may still have many questions about how best to conduct individual tests and what they are actually testing for.

Given the possible variation of the AELS evaluation training and protocol among evaluators, it is challenging to make the case for reliability and validity of the results. To recap, it seems that a high-stakes language proficiency test is being delivered with limited test design guidance, minimal assessor training and norming, and very little standardization between (or even within) training organizations. Clearly, there is increased likelihood for results that do not accurately identify candidates' language ability. Future research is needed to further understand the current practice among FTOs in regards to the FAA AELS procedure. There appears to be a need for a revised FAA AELS procedure that is more congruent with the larger scope of ICAO's guidance to involve language testing experts in the design and administration of aviation English proficiency testing (ICAO, 2010, 6-24, 6.3.8.3).

In addition to a revised AELS procedure, there is an immediate need to implement a valid and standardized screening test for aviation-specific English proficiency taken prior to admission to a flight training program. The use of a screening test helps lighten the burden of language testing for aviation examiners during flight training. More important, the results of the screening test would also have a diagnostic function to identify flight training candidates for whom targeted aviation English support would increase their chance of success in the program. In the case of a low proficiency candidate, the test may alert the training organization that the prospective student needs foundational English training prior to aviation English supplementation.

The current discussion illustrates the need for the widespread and consistent use of an aviationspecific English proficiency screening test by FTOs in the United States. The use of such a test could provide an additional layer of risk mitigation as well as identify flight training candidates for whom targeted aviation language support will increase their chance of success in the program. 


\section{Defining the flight training domain}

To identify the necessary components of an appropriate screening test for flight training candidates, the flight training context needs to be specified. Despite variation between programs and among instructors, the domain of flight training in the US can be defined generally. Roberts and Orr (2020) allude to the complex and varied nature of speaking skills required of flight students which span from classroom discourse to interaction in the cockpit, as well as with ATC. Udell, Schneider and Kim (forthcoming) conducted a study to begin identifying key tasks and target language features within the flight training domain through a needs analysis comprised of interviews, observations of various activities done during flight training, and a survey of flight instructors.

To more fully understand this domain for the purpose of an English proficiency test, however, we must continue to employ linguistic tools. Knoch and Macqueen (2020) advocate for the use of discourse analysis and corpus analysis to identify patterns and feature frequency in specific domains. Friginal et al. (2020) along with colleague Zhang, encourage the use of corpora as a primary driver of aviation English test development. They define an aviation English corpus as the "systematic compilation of naturally occurring language in the aviation industry" (p.112) and highlight that language is used differently in different sub registers within aviation English, such as the difference between the operational pilot domain compared to the flight training domain. Therefore the systematic collection of language used in the flight training context, including both transcribed and annotated spoken language of interactions between student and instructor in the classroom and in the aircraft, as well as a corpus of written texts used during training, is necessary for the development of a test that measures language abilities that are actually needed in flight training.

The following description will attempt to identify ways in which the flight training context may be considered a domain on its own due to its distinctive features, and highlight areas where further research is necessary to confirm or refute anecdotal evidence identifying key communicative tasks.

\subsection{Emerging descriptions of the flight training domain}

Udell, Schneider and Kim (forthcoming) aptly noted the tendency of anecdotal and survey evidence to guide the understanding of the flight training domain as well as where students struggle. Their research focused on identifying key tasks in flight training, and then observing and recording target language during these tasks. As summarized in Table 1, their discussion emphasizes the need for students to read a variety of text types and listen for numerous purposes. Not surprisingly, many tasks they identified required reading and listening to be integrated with speaking to demonstrate comprehension, 
both for learning and assessment with the instructor, and as part of aviation operations. The tasks identified in Udell, Schneider and Kim's forthcoming research help to sketch out the domain of flight training.

Table 1. Key tasks identified in the flight training context (UDELL; SCHNEIDER; KIM, forthcoming)

\begin{tabular}{|l|l|}
\hline \multicolumn{1}{|c|}{ Skill } & \multicolumn{1}{c|}{ Example Tasks and Texts } \\
\hline Reading & handbooks, NOTAMs ${ }^{9}$, diagrams \\
\hline Listening & lectures, ATIS ${ }^{10}$, ATC directions $^{-1}$ during flight, explaining regulations, answering scenario- \\
\hline Integrated skills & $\begin{array}{l}\text { performing call-outs } \\
\text { based questions, completing checklists, participating in debriefing sessions }\end{array}$ \\
\hline
\end{tabular}

\subsection{Flight instructor-student relationship}

The FAA explains in their Student Pilot Guide that "the flight instructor assumes total responsibility for training [flight students] to meet the standards required for certification" (2016, p. 4). Not surprisingly then, most of the tasks identified by flight instructors in Udell, Schneider and Kim's forthcoming research involve the instructor and student interacting directly. Students and instructors have anecdotally reported the need for flight students to be able to orally paraphrase information, discuss a plan for future actions, decide the ethics of a hypothetical violation of regulations, and recall and reflect on events from a flight during a debriefing. Consequently, the student may be held more accountable for their knowledge than in an academic classroom with many other students present. Likewise, willingness and ability to ask questions could be another key aspect to successful flight training as the FAA's Student Pilot Guide advises that "after each flight, the flight instructor will review the day's lesson. This will be the time to clear up any questions" (2016, p.4).

The one-to-one instruction and interaction happen not only in classroom-like settings, but also in flight training devices (e.g., simulators), in common areas and lobbies, outside near the aircraft, and inside the aircraft while in operation. These dynamic environments may affect the interaction; for example, proximity and orientation of interlocutors to one another and noise level can inhibit normal communication. Another unique feature is the real-time instruction-giving that flight instructors do in the

\footnotetext{
${ }^{9}$ A NOTAM, or notice to airmen, is defined by the FAA (2020) as "a notice containing information (not known sufficiently in advance to publicize by other means) concerning the establishment, condition, or change in any component (facility, service, or procedure of, or hazard in the National Airspace System) the timely knowledge of which is essential to personnel concerned with flight operations."

${ }^{10}$ The ATIS (automated terminal information system) is a continuous broadcast of local weather and airport information that pilots listen to prior to departure and arrival (ICAO, 2016).

${ }^{11}$ Call-outs (i.e., standard calls) are short, standardized utterances used to accomplish a variety of crew communication functions including giving and acknowledging instruction, completing checklists, or asking questions (FLIGHT SAFETY FOUNDATION, 2000).
} 
aircraft. Udell, Schneider and Kim (forthcoming) highlight the role of multitasking during this time (e.g., listening to the instructor, ATC, weather broadcasts, reading back information, taking notes, performing checklists). Anecdotally, flight instructors have emphasized the need for immediate response and/or action from the flight student. These characteristics appear to be notably different from the traditional academic classroom lecture due to the active role of the student, time sensitivity of comprehension and response, as well as the variety of physical environments in which the instruction takes place.

Because of the deep involvement of the flight instructor and due to the stressful environment of flight training, it is logical to believe that building trust and rapport is important for a successful studentinstructor relationship. Flight instructor participants in Udell, Schneider and Kim's study (forthcoming) identified communication both inside and outside of training (e.g., scheduling) as tasks related to training. This could emphasize the need for interpersonal and phatic communication skills more typical of conversational English as defined by Biber and Conrad (2009). Future studies could seek to understand the extent to which conversational English and relationship building contributes to success in flight training.

To gain a more accurate depiction of the flight training domain and skills needed, corpus creation and analysis, as well as additional surveys and observation could help test developers validate intuition and anecdote about frequent and/or critical communicative tasks.

\subsection{Radio communication}

Like operational pilots and ATCOs, flight students use radio communications and are thus subject to the same domain features summarized in ICAO Document 9835 (2010) (e.g., phraseology, aviation terminology, poor acoustic environment). The conventions and phraseology of these radio skills are typically taught during flight training (CAMPBELL-LAIRD, 2006). However, the ability to listen for specific information given at a rapid pace, as well as the ability to speak clearly and spontaneously is foundational to learning to communicate in this domain.

An additional component of this domain in the US is that student pilots are interacting with or listening to professional ATCOs and pilots who are native English speakers. Researchers in this field have noted the tendency of native English speaking (NES) pilots and ATCOs to use plain language even when standard phraseology is available ${ }^{12}$ (e.g., KIM, 2012). Therefore, the reality of communicating on the radio in US airspace requires the ability to cope with interlocutors who may use plain language instead of standard phraseology. This may be less of a problem for NES flight students, but an additional challenge

\footnotetext{
${ }^{12}$ However, according to ICAO Annex 10 "only when standardized phraseology cannot serve an intended transmission, plain language shall be used" (ICAO, Annex 10, Vol. II, 5.1.1.1, 5-1) by pilots and controllers.
} 
for NNES students. Campbell-Laird's (2006) study reported that in unexpected circumstances, NNES flight students were less likely to be able to cope with the demand for plain language required outside of the standard phraseology they had learned. Analysis of corpus data could illuminate areas of difficulty for NNES flight students and use that information to inform the design of the proposed screening test.

\subsection{Building knowledge through reading}

In addition to the listening and speaking tasks that comprise the flight training domain, reading also appears to play a critical role. The FAA Student Pilot Guide (2016) directs flight students to several substantial handbooks, manuals, and documents. These include the Aeronautical Information Manual (752 pages), Pilot's Handbook of Aeronautical Knowledge (524 pages), and the Airplane Flying Handbook (348 pages). Individual FTOs may also prepare proprietary standard operating procedure manuals for their students, in addition to any textbooks or online readings required. Besides written text, diagrams, charts, and other means of visually presenting information may take an important role in flight training.

Nearly one-third of the tasks identified by flight instructors in Udell, Schneider and Kim's research (forthcoming) included a reading component (e.g., reading handbooks, reading charts and diagrams, reading checklists). Further observation of how information from written/visual texts are employed during flight training would shed light on not only which texts and text types are most common, but also what kind of reading skills and subskills are most crucial to success in flight training. Corpus analysis of these texts could illuminate frequency of particular features or structures. Gaining a clearer understanding of the role of reading in flight training is important to designing any screening test of candidates' abilities.

The language skills needed to thrive in the flight training domain appear to be much broader than those of an operational pilot; more specialized than what typical oral proficiency interviews measure; and more focused on oral skills than EAP tests assess. Building on the forthcoming work of Udell, Schneider and $\mathrm{Kim}$, future research should continue to investigate the flight training domain in further detail to help identify areas of focus for the most effective screening assessment.

\section{Language proficiency screening tests and FTOs}

To screen flight training candidates, we propose that FTOs employ a language proficiency test that adequately represents the flight training context. In general, these kinds of tests measure a candidate's "level of language ability, but without respect to a particular curriculum" (CARR, 2011, p. 325) and are used for screening and placement in many settings, including applications for schooling, university (e.g. TOEFL and IELTS), intensive English programs, jobs and citizenship. Unlike achievement tests based on a particular syllabus or curriculum, proficiency tests are built upon theories of language ability 
(BACHMAN; PALMER, 2010) and their main aim is to provide global information about a candidate's language competence (WEIGLE; MALONE, 2016).

A meaningful proficiency assessment is one that elicits a candidate's ability to use language in the ways they will use it in real life. Thus, determining which language to test requires an understanding of the target use domain, or situations, in which language will be used (BACHMAN; PALMER, 2010). In the following paragraphs we will describe three tests that might be used to screen flight training candidates, but were originally designed for other domains: general English oral proficiency interviews, English for academic purposes tests and ICAO English tests.

\subsection{General English proficiency: domain and test characteristics}

Thinking about an incoming NNES flight student with very little (if any) aviation knowledge or experience, a logical first step might be to look to a general test of spoken language proficiency. This is because speaking skills are necessary in safety-critical communication such as call outs ${ }^{13}$ (FLIGHT SAFETY FOUNDATION, 2000) during flight, but also consequential to student progress in tasks such as explaining a regulation (UDELL; SCHNEIDER; KIM, forthcoming).

An oft-cited and long standing oral proficiency test is the American Council of the Teaching of Foreign Languages Oral Proficiency Interview (ACTFL OPI). This interview "is an assessment of a speaker's functional language ability" (SWENDER; VICARS, 2012, p. 1). ACTFL claims a variety of applications for its test scores including broad domains where functional language use is necessary, such as work or study, but only insofar as the speaker's "ability to use language effectively and appropriately in real-life situations" (SWENDER; VICARS, 2012, p.1). The scope for tests such as the ACTFL OPI is limited to speaking and listening; and the domain appears to encompass everyday interactions with interlocutors of similar social status on familiar, non-technical topics with few environmental disruptions or constraints on communication.

The goal of an OPI is to elicit a speaker's oral proficiency through a series of questions, typically following a pre-determined protocol with room for adaptation by the trained interviewer. The speaker's sample is then rated by trained raters. The benefit of this type of interview is live interaction which creates an authentic and dynamic environment for language use. The ACTFL OPI uses an underlying elicitation structure that is adapted to each candidate's interests by the interviewer (SWENDER; VICARS, 2012). The interviewer uses a brief warm up session with the candidate to elicit topics of interest and then builds these topics into the OPI elicitation structure as the interview progresses. The interview is then doublerated based on the ACTFL Proficiency Guidelines 2012 - Speaking (ACTFL, 2012). Interviewers and

\footnotetext{
${ }^{13}$ Flight Safety Foundation stated that "standard calls reduce the risk of tactical (short-term) decision-making errors" (2000, p. 21).
} 
raters undergo up to a year of training, calibration, and practice interviewing before becoming certified. An obvious challenge with delivering this type of test is practicality. Scheduling, conducting, and rating an OPI for each candidate is necessarily a time-consuming and resource-heavy endeavor as it requires a significant time commitment from skilled trainers, interviewers, and raters.

In essence, an OPI is meant to assess proficiency in everyday English, a great part of which, as Biber and Conrad (2009) observe, consists of conversations where speakers prioritize sharing their own feelings and attitudes to build a relationship with the interlocutor. Although flight students will undoubtedly use everyday English to some extent, the more consequential aspects, namely learning aviation content and following instructions, may have characteristics different from conversation; more focused on factual information exchange. Moreover, a test like the ACTFL OPI completely excludes the component of reading, which is a necessary skill to screen flight training candidates for. In brief, the very general nature of this type of test likely does not provide sufficient information to adequately screen flight training candidates.

\subsection{English for academic purposes tests}

Already widely used to screen applicants in many universities where English is the medium of instruction, English for Academic Purposes (EAP) tests are another common method for FTOs to screen candidates. They may seem to be a logical choice since the flight training domain shares some features with the academic domain, such as listening to lectures, taking notes, reading a variety of texts, and summarizing information. However, this overlap may not account for important differences.

Academic English has been traditionally associated with writing essays, reports and examination answers, reading textbooks and research articles, and listening to lectures (DUDLEY-EVANS; ST JOHN, 1998; BIBER, 2006; HYLAND; SHAW, 2016). According to Biber (2006), EAP could be essentially divided in two: on the one hand, the educational subdomain, which comprises - but is not limited to lectures, classes, textbooks, office hours and study groups; on the other hand, the institutional subdomain, which is composed by service encounters, catalogs, university brochures and magazines, among other registers and genres (BIBER et al., 2004; BIBER, 2006). While the language used in the institutional subdomain is basically the same for all university students, research has shown that language in the educational subdomain differs considerably across subject areas (BIBER, 2006; DURRANT, 2014; HYLAND; TSE, 2007), with each discipline "draw[ing] on different lexical, grammatical, and rhetorical resources to create specialized knowledge" (HYLAND; SHAW, 2016, p. 21). This is why there are two essential ways to look at EAP: a more general perspective, which focuses on core transferable skills, such as scanning, skimming, paraphrasing, summarizing and taking notes; and a more specific one, which takes into account disciplinary variability and targets learners' discipline-specific needs (HYLAND, 2016). 
EAP tests usually follow the general perspective, because they need to accomplish two objectives: First, they need to simulate as much as possible an academic context in terms of the content, language, and tasks (WEIGLE; MALONE, 2016); second, they also need to be valid for a wide range of academic institutions and tackle a variety of disciplines (from biology to anthropology, from linguistics to geology).

Nowadays, there are three main EAP tests available on the market: TOEFL, in the IBT (internetbased) and ITP (institutional) versions ${ }^{14}$, IELTS and PTE-Academic. From the features shown in Table 2, we can see most of the tests cover the four skills (reading, listening, writing and speaking) but only some include items that test integrated skills (e.g. reading and writing or listening and speaking), so ubiquitous in the academic environment. In fact, students will often learn from reading and listening and will later be expected to reproduce their knowledge in writing, for instance in the form of essays or written exams. The tests also differ in their delivery format (online or face-to-face) as well as in the way they are assessed (by automated tools or human raters).

Although there are important differences in the ways these tests are designed and delivered, all of them present a similar communicative approach and focus on Academic English, by requesting candidates to read, listen and produce registers and genres that are typical of this domain. It is also important to remember that the tests' overall scores, which are usually the measure universities base their admissions requirements on, reflect the candidate's performance in all the skills combined ${ }^{15}$. The overall score format combined with the fact that these tests take a more general, rather than specific, perspective on EAP may result in failure to assess the academic language students will actually need in their courses or in inaccuracies regarding candidates' language proficiency. In other words, the test scores may not "reflect a student's ability to succeed in specific subject areas" (WEIGLE; MALONE, 2016, p. 612), which could be the case when EAP tests are used to screen flight training candidates. For instance, a candidate may fail to achieve a passing score due to poor performance in academic writing, a skill that is less relevant to the flight training domain. Conversely, another candidate may achieve a global passing score thanks to their high performance in academic writing while disguising a lower score in a much more crucial ability, such as speaking. As a result, EAP tests are likely another less-suitable option to screen flight training candidates.

\footnotetext{
${ }^{14}$ There are currently two versions of TOEFL ITP: level 1, for intermediate to advanced students, and level 2, for high-beginner to intermediate students.

${ }^{15}$ In their score reports, students can see their performance in each skill, but universities usually set their minimum language requirements based on the global scores.
} 
Table 2. Salient features of selected EAP tests

\begin{tabular}{|c|c|c|c|c|c|}
\hline \multicolumn{2}{|c|}{ Test features } & \multicolumn{2}{|c|}{ TOEFL } & \multirow{3}{*}{$\begin{array}{c}\text { IELTS } \\
\checkmark\end{array}$} & \multirow{3}{*}{$\begin{array}{c}\text { PTE-Academic } \\
\checkmark\end{array}$} \\
\hline & & \multirow{2}{*}{$\frac{\text { IBT }}{\checkmark}$} & \multirow{2}{*}{$\frac{\text { ITP }}{\checkmark}$} & & \\
\hline \multirow{6}{*}{$\begin{array}{l}\text { Test } \\
\text { sections } \\
\text { and tasks }\end{array}$} & Reading & & & & \\
\hline & Listening & $\checkmark$ & $\checkmark$ & $\checkmark$ & $\checkmark$ \\
\hline & Writing & $\checkmark$ & - & $\sqrt{ }$ & $\checkmark$ \\
\hline & Speaking & $\checkmark$ & - & $\checkmark$ & $\checkmark$ \\
\hline & $\begin{array}{l}\text { Integrated } \\
\text { skills }\end{array}$ & $\checkmark$ & - & - & $\checkmark$ \\
\hline & $\begin{array}{l}\text { Structure } \\
\text { and written } \\
\text { expression }\end{array}$ & - & $\checkmark$ & - & - \\
\hline \multirow[t]{2}{*}{$\begin{array}{l}\text { Test } \\
\text { delivery }\end{array}$} & $\begin{array}{l}\text { Computer- } \\
\text { delivered }\end{array}$ & $\checkmark$ & - & $-/ \sqrt{ }$ & $\checkmark$ \\
\hline & Live element & - & - & $\checkmark$ & \\
\hline \multirow{2}{*}{$\begin{array}{l}\text { Rating of } \\
\text { productive } \\
\text { skills }\end{array}$} & $\begin{array}{l}\text { Automated } \\
\text { tools only }\end{array}$ & - & - & - & $\checkmark$ \\
\hline & $\begin{array}{l}\text { Automated } \\
\text { tools and } \\
\text { human raters }\end{array}$ & $\checkmark$ & - & $\checkmark$ & - \\
\hline \multirow[t]{3}{*}{ Scores } & $\begin{array}{l}\text { Equal weight } \\
\text { for each skill }\end{array}$ & $\begin{array}{c}\checkmark \\
30 \text { points }\end{array}$ & $\begin{array}{c}\checkmark \\
67-68 \text { points }\end{array}$ & $\begin{array}{c}\checkmark \\
1-9 \text { band }\end{array}$ & $\begin{array}{c}\checkmark \\
10-90 \text { range }\end{array}$ \\
\hline & $\begin{array}{l}\text { Other } \\
\text { elements }\end{array}$ & - & $\begin{array}{l}\text { Structure and } \\
\text { written } \\
\text { expression } \\
\end{array}$ & - & $\begin{array}{c}\text { enabling skills } \\
10-90^{16}\end{array}$ \\
\hline & $\begin{array}{l}\text { Overall } \\
\text { score }\end{array}$ & $\begin{array}{l}\text { Marked out } \\
\text { of } 120\end{array}$ & $\begin{array}{l}\text { Level 1: from } \\
310 \text { to } 677 \\
\text { Level } 2 \text { : from } \\
200 \text { to } 500 .\end{array}$ & $1-9$ band & Range from $10-90$. \\
\hline
\end{tabular}

$\checkmark$ : indicates the presence of the specific feature in the test; -: indicates lack of the specific feature in the test; $\sqrt{ } /$-: indicates that the presence or absence of the specific feature depends on which version of the test the candidate takes.

\subsection{Aviation English tests for professional pilots and air traffic controllers}

As we have seen, EAP tests include tasks that are irrelevant to flight training (e.g., essay and report writing), but are also likely too broad in content (e.g., readings and lectures on diverse topics unrelated to aviation) to accurately assess readiness for the flight training domain. It might then be logical to look toward tests designed for pilots and air traffic controllers to better represent the domain of aviation English; however, there are several important differences between the operational domain and the flight training domain.

\footnotetext{
${ }^{16}$ In the PTE Tests, grammar, oral fluency, pronunciation, spelling, vocabulary and written discourse are considered "enabling skills" (NEWBOLD, 2017).
} 
Aeronautical radiotelephony communications comprise a specific domain particular to air traffic controllers and pilots outlined in ICAO Document 9835 (2010, p. 3-2). To summarize, this domain is restricted to listening and speaking skills, involves significant aviation-specific technical knowledge, and often separates interlocutors from shared points of visual and spatial reference (e.g., an ATCO in the tower and a pilot in the air). Moreover, communication in this domain often relies on voice-only communication, removes paralinguistic cues, requires that speakers not overlap transmissions, and is affected by static, background noise, and imperfect microphone technique. A key characteristic of this domain is the standard radiotelephony phraseology used by pilots and controllers. Phraseology comprises a relatively small, specific subset of language used in a particular way (PHILPS, 1991) and for particular communicative functions ${ }^{17}$. This phraseology utilizes English words and phrases, but could be seen as a separate register of English which must be learned, even by native English speakers. However, because phraseology does not always cover language required in non-routine or emergency situations, the need for aviation personnel to also have sufficient plain language has been well-documented (e.g., MATHEWS, 2001; FRIGINAL et al., 2020; ICAO, 2010). To better understand the characteristics of plain language used in non-routine situations for which phraseology may not be sufficient, Prado and Tosqui-Lucks' (2019) work designing the Radiotelephony Plain English Corpus (RPTEC) is shedding light on this crucial linguistic aspect of the professional pilot and ATCO domain.

Following the guidance of ICAO Document 9835, many member states have implemented their own tests for pilots and controllers to certify that they are at least Operational Level 4 . As there is variation in quality of these tests (ALDERSON, 2010), the International Civil Aviation English Association (ICAEA) has proposed test design guidelines to assist ICAO member states in evaluating their assessments. The first criterion is that the test must assess "communication skills in aeronautical radiotelephony contexts" (ICAEA, 2019). Because of the emphasis on radiotelephony in the target domain, these criteria, like the ICAO rating scale, focus solely on listening and speaking skills. While there is variety among these assessments, most of them include a live interview component that covers operational aviation knowledge. Many tests include some type of role-play, and there are a variety of other tasks that might be included, such as a discrete listening section or a picture description. In addition to plain English proficiency, pilots and ATCOs are typically accountable for operational aviation knowledge and ICAO phraseology during these tests.

\footnotetext{
17 Mell and Godmet's (1997) work was included in ICAO Document 9835, Appendix B: Language of Aeronautical Radiotelephony Communications, where four major categories of communicative functions were identified: those intended to trigger an action, share information, manage pilot-ATC relationship, and manage the dialogue.
} 
In sum, these tests and their ratings only have a valid application in certifying operational pilots and ATCOs. The test scope is too narrow in terms of language skills and the test content is too aviation knowledge-dependent for flight training candidates who need more varied skills, but for whom there can be no expectation of operational knowledge or phraseology.

Table 3. Comparison of OPI, EAP and ICAO English tests

\begin{tabular}{|c|c|c|c|c|c|}
\hline & & $\begin{array}{c}\text { Oral } \\
\text { Proficiency } \\
\text { Interviews }\end{array}$ & $\begin{array}{l}\text { English for } \\
\text { Academic } \\
\text { Purposes }\end{array}$ & $\begin{array}{c}\text { ICAO English } \\
\text { tests }\end{array}$ & $\begin{array}{c}\text { Degree of relevance } \\
\text { for screening } \\
\text { student pilot } \\
\text { candidates }\end{array}$ \\
\hline \multirow[t]{3}{*}{$\begin{array}{l}\text { Focus } \\
\text { domain }\end{array}$} & $\begin{array}{l}\text { Everyday } \\
\text { English }\end{array}$ & $\checkmark$ & - & - & Some \\
\hline & $\begin{array}{l}\text { Academic } \\
\text { English }\end{array}$ & & $\checkmark$ & - & Some \\
\hline & $\begin{array}{l}\text { Aeronautical } \\
\text { radiotelephony } \\
\text { communications }\end{array}$ & - & - & $\checkmark$ & None \\
\hline \multirow[t]{4}{*}{ Skills } & Reading & - & $\checkmark$ & - & High \\
\hline & Listening & $\checkmark$ & $\checkmark$ & $\checkmark$ & High \\
\hline & Speaking & $\checkmark$ & $\checkmark$ & $\checkmark$ & High \\
\hline & Writing & - & $\checkmark$ & - & Limited \\
\hline \multirow[t]{2}{*}{ Scores } & Overall scores & $\checkmark$ & $\checkmark$ & $\checkmark$ & High \\
\hline & $\begin{array}{l}\text { Skill-specific } \\
\text { scores }\end{array}$ & - & $\checkmark$ & $\checkmark$ & High \\
\hline
\end{tabular}

$\checkmark$ : indicates the presence of the specific feature in the test; -: indicates the absence of the specific feature in the test.

Looking at three domains that share some of the characteristics of flight training, the existing tests in these areas would be inadequate or inappropriate measures for flight training candidates (see Table 3). The nebulous domain for an oral proficiency interview is limited in skill types tested and may lack face validity in the aviation community due to the very general content. Academic English tests include elements that are irrelevant to flight training, but more problematically, flight training organizations may accept composite scores, potentially masking a candidate's underdeveloped skill in a key area, such as speaking. Tests for operational pilots are too in-depth in terms of aviation content, yet not broad enough in language skills tested. The issue of practicality arises with OPIs and any live components of EAP or ICAO testing as well. All of these tests can be relatively expensive, plus any costs associated with traveling to a testing center. FTOs are unlikely to want to invest in footing the cost of a screening test which may not provide a complete picture of a candidate's skills; and should FTOs choose to pass along the cost to the applicants, prospective students might choose schools with lower fees or fewer barriers. 
The solution for flight training organizations is not as simple as employing an existing language test. Campbell-Laird (2006) reported that nearly three-quarters of university-based flight schools had a minimum TOEFL PBT score of $500-550^{18}$, roughly equivalent to IELTS 6 . These scores could be broadly categorized as representing an upper-intermediate level of English ability ${ }^{19}$. Further, in Campbell-Laird's (2006) study, she reported that some FTOs implemented higher TOEFL requirements to avoid offering aviation English support classes. Dusenbury and Bjerke's (2013) research suggested that higher scores on English screening tests link to both higher academic grades and better flight performance. However, this broad-brush approach to set higher scores on such tests could screen out candidates who have the abilities for flight training, but lack some of the less relevant academic skills tested.

Setting a higher cut score on an existing test such as the TOEFL might screen out low proficiency candidates, but may also result in FTOs turning away candidates who indeed have the skills needed for flight training or those who simply need aviation English training. Along these lines, many in the aviation English community have urged that more targeted screening for language proficiency is essential to provide adequate support for candidates as they enter flight training (ALBRITTON, 2007; FRIGINAL et al., 2020; ROBERTS; ORR, 2020).

\section{Checkpoint: an example of a flight training English proficiency test}

So far, we have claimed that a more effective way to screen candidates who apply to FTOs would be through a test that addresses the distinctive features of the flight training domain as well as the language skills students will actually need in their training. This is a point that has been getting increasing attention (see ALBRITTON, 2007; EMERY, 2014, 2016; FRIGINAL et al., 2020) and in recent years there have been initiatives towards the actual implementation of such a test. Below, we will discuss Checkpoint, a test that has been available for several years.

Launched in 2014 by Latitude Aviation English Services, Checkpoint is a web-delivered test specifically designed for both flight and ATC training candidates who intend to start training in any EMI aviation training organization (ATO) around the world (LATITUDE, 2017b, 2017c; EMERY; GLIDDON, 2019). Unlike the general English and EAP tests discussed above, Checkpoint focuses exclusively on the skills that are necessary in aviation training (i.e., listening, reading and speaking) as well as on the specific language that student pilots and controllers will need in their courses (EMERY,

\footnotetext{
18 The TOEFL PBT (and CBT of the time) did not include speaking sections. the TOEFL PBT (paper-based) was discontinued in 2017 and the CBT was superseded by the IBT in 2005. The scores reported in Campbell-Laird's work can be associated with current TOEFL iBT scores between 61-80, though the comparison is incomplete due to lack of a speaking section.

19 These scores could be associated with a B1 to B2 level on the Common European Framework of Reference (PAPAGEORGIOU, TANNENBAUM, BRIDGEMAN; CHO, 2015).
} 
2014), which is basically "the formal, generic English common in the teaching of STEM [Science, Technology, Engineering and Mathematics] subjects" (LATITUDE, 2017b, p.11). It also differs from ICAO exams as it does not focus predominantly on RT communication, but on spoken and written texts that are typical in ATOs, such as students' conversations with staff and classmates, classes, informationdense textbooks and aeronautical documents.

To ensure that the context, language, and abilities addressed in Checkpoint resemble those encountered in real-life aviation training, a description of the domain was carried out through an analysis of syllabi and courseware and through observation of ATO staff and students in training and trainingrelated activities (LATITUDE, 2017b). Domain specialists, such as operational personnel and experienced aviation English instructors, were also instrumental in designing the test, as they helped by pointing out the skills that should be assessed and the information that the test scores should convey (LATITUDE, 2017a). Once all this information was collected, the items for each part of the test were designed and tested.

The first part is the listening test, which includes three types of interaction: a dialogue between a student and training center staff, a more informal interaction among students and an instructor's technical monologue followed by a short instructor-student interaction. While Latitude mentions that the audio passages are recorded by professional actors in NES and NNES accents, there is a lack of information on the process of creating the scripts for these interactions (LATITUDE, 2017a, 2017b, 2017c). The tasks, which involve listening to recorded conversations and answering multiple-choice questions, are designed to assess specific listening abilities that are essential for these students (LATITUDE, 2017a).

The reading section is composed of passages extracted from four different sources: the ICAO Document 4444, the US FAA Aeronautical Information Manual (AIM), UK air accident investigation reports and articles from aviation industry journals on training, safety and management. All the tasks are multiple-choice and involve answering questions, completing sentences, matching paragraphs and marking whether some information is true, false or not given in the text. From the reports available on the Latitude website, it is not clear which specific listening and reading subskills are actually tested in the listening and reading sections. In fact, the test developers admit that "mapping reading and listening test items to language abilities" (LATITUDE, 2017b) is still one of the future steps to further investigate Checkpoint validity.

Finally, the speaking part consists of three tasks: in the first, candidates describe an animation or sequence of pictures that depict an aeronautical process or mechanism; in the second, they narrate an accident or incident from a storyboard; in the last, they read (or listen to) and answer three questions on the aviation industry and on their future career. The speaking part lasts ten minutes in total, during which 
the candidate can talk for a maximum of 4 minutes and 20 seconds. Unlike the automatically scored listening and reading sections, the speaking part is recorded and later assessed by trained and certified raters through specific criteria, such as task fulfillment, pronunciation, structure, vocabulary and fluency.

Performance in the test is reported using a traffic-light scoring system for each skill: a green score in all skills suggests that the candidate is unlikely to have any language-related difficulties in flight training, a yellow score in one or more skills indicates that additional language classes are recommended, and a red score in one or more skills should be interpreted as a strong need for intensive language training. As we have seen, the choice of reporting separate results for each of the listening, reading and speaking tests is a sensible one as it avoids a misrepresentation of a candidate's proficiency.

By addressing many of the concerns that have been mentioned above on the use of other tests to screen ATO candidates, Checkpoint seems to be a more adequate option as it focuses on the aviation training context and, therefore, has better chances of assessing candidates' proficiency and predicting whether they will encounter language obstacles in their training. However, there are several considerations that suggest an alternative test is needed.

\section{Checkpoint and US flight training}

To begin, Checkpoint is meant both for flight and ATC training candidates, which broadens the scope significantly. ICAEA's (2020) test design guidelines for ICAO Operational Level 4 testing urge that "separate test instruments need to be designed for pilots and air traffic controllers" because the communication needs of these groups differ. Because students in these two areas will likely have quite different communication needs, it is logical to extend ICAEA's guidance to screening tests as well. For flight students, it seems that the majority of communication during flight training happens between student and instructor, not only in the aircraft, but also during the pre-flight briefing and post-flight debriefing; as well as in any flight training device sessions and oral activities or exams. Due to the bearing of student's English proficiency on their ability to participate in flight training safely, we agree with Emery (2016) that the priority for a screening test must be to determine students' ability to learn effectively and understand instructions in English, but also to communicate clearly and with confidence; though we would advocate for separate tests to be created for flight and ATC training candidates.

\subsection{Speaking Section}

Based on the growing understanding of the flight training domain, speaking skills are crucial to evaluate among prospective flight students. The speaking section of Checkpoint may not give adequate information about the linguistic obstacles that a flight student might encounter during training. At just 
over four minutes of speech sample, Checkpoint's raters may not have sufficient evidence of the speaker's ability. By contrast, in ACTFL's Oral Proficiency Interview (OPI) model, 20-30 minutes of speech are typically elicited from a candidate to assess their proficiency.

Looking at speaking task types, in Checkpoint's interview section, candidates are asked to talk about their futures in aviation and the aviation industry in general. The purpose of this question type is unclear. Moreover, the other tasks types in Checkpoint focus on description and narration related to images and animations. The abilities to describe and narrate have traditionally been used to test the upper bounds of an intermediate speaker (such as in the ACTFL OPI). On the other hand, the ability to hypothesize, propose alternatives, and support an opinion on an abstract concept are used to discriminate among higher levels of language ability in well-worn tests like the ACTFL OPI. These advanced skills are echoed in Udell, Schneider and Kim's (forthcoming) observations, especially regarding scenariobased questions and self-evaluating strengths and weaknesses during debriefing sessions. For the proposed test, higher-level language skills should be elicited to offer sufficient discrimination among candidates, especially those with higher abilities who may thus require less aviation English support.

Flight training candidates should encounter not only stand-alone speaking questions, but also integrated speaking tasks that ask them to read or listen to information and then talk about it. The tasks identified by Udell, Schneider and Kim (forthcoming) reflect the need for integration, such as reading and explaining a regulation or listening and taking notes to read back. Given the linguistic (and in some ways, academic) challenges presented by flight training, candidates need to have ample opportunity to demonstrate their English speaking ability in a variety of ways, from more basic prompts related to one's own experience to more advanced and integrated prompts built on authentic texts that require candidates to incorporate information into their speech.

Overall, it is important that flight training candidates are thoroughly screened in their speaking abilities; therefore, a more robust speaking component with integrated skills is necessary.

\subsection{Listening Section}

To match the diversity of linguistic demands during flight training, Checkpoint rightly aims to test listening in a variety of situations associated with this domain. It is unclear, though, how Checkpoint developers carried out their observations and how course syllabi and courseware were analyzed. To build upon Checkpoint's approach, a test for the US context should include a diverse range of discrete and integrated listening tasks. Listening tasks built around student-instructor interaction are key to such a test. To prioritize evaluation of the speaking and listening skills with the highest consequence in the flight training environment, interactions between training center staff and student to student communication 
might be replaced with other listening opportunities such as the ATIS, recorded one-to-one instruction, and pilot training videos ${ }^{20}$.

\subsection{Reading Section}

The use of selected authentic aviation reading materials in the Checkpoint test sets a strong example for this type of test. In addition to a more accurate depiction of the target language use domain, these texts provide strong face validity for test candidates and FTOs. Adding to Checkpoint's use of the US FAA Aeronautical Information Manual (AIM), we propose that such a test draw a wider variety of texts used during flight training in the US context. For a start, the texts mentioned in the FAA Student Pilot Guide should be included. If obtainable, samples of written training materials and manuals prepared for students at individual flight schools could provide a rich source of information as well. A corpus of flight training reading material will offer insight into quantitative measures of these texts, but the use of a systematic qualitative approach will yield genre and register information to help test developers identify reading passages that are representative of the materials they are likely to encounter in flight training.

To build upon the use of authentic materials, more authentic task types are proposed to elicit the specific language skills that will be required of flight students in the US. Flight instructors identified reading for the purpose of learning and explaining, as well as reading checklist items aloud, and using information from charts as key tasks (UDELL; SCHNEIDER; KIM, forthcoming). Additional research could focus on the role of reading in flight training to further flesh out our understanding of this domain and help test developers elicit the most critical skills.

\subsection{Input from experts and the role of aviation content}

Building upon the process undertaken by Checkpoint and the forthcoming work of Udell, Schneider and Kim, the flight training domain in the US context must be more clearly identified. Understanding this domain will entail on-going collaboration with domain experts and observation to identify key communicative tasks as well as understanding what language is required to complete those tasks (i.e., corpus and discourse analysis). Knoch and McQueen (2020) propose that tasks act as the foundation of test development because domain experts (e.g., in this case flight instructors) recognize these tasks within the test and can help test developers understand how these tasks are evaluated in the real world and therefore inform how the task might be evaluated in the language test.

\footnotetext{
${ }^{20}$ Degree of authenticity is an especially important and complex subject in testing language for professional or specific purposes (KNOCH; MACQUEEN, 2020). However, the drive for authenticity should not preclude the need for test tasks and text adaptations (such as a simplified ATIS) that are accessible to lower level candidates who still need to receive an adequate appraisal of their current skills in order to receive appropriate training.
} 
In addition to tasks and language use, a significant consideration for the proposed test is how aviation content will be integrated. The incorporation of aviation content is critical for face validity of the test for stakeholders including FTOs and flight training candidates. More importantly, aviation content plays a role in the key tasks in the domain, so to exclude it entirely would reduce the representativeness of the test. Conversely, these prospective students are what Knoch and McQueen (2020) call "layperson" test-takers. These candidates cannot be expected to be familiar with aviation concepts, but rather they must be able to use a more general proficiency to learn and interact successfully ground school and flight training. Checkpoint's solution found middle ground in selecting general STEM topics relevant to aviation (LATITUDE, 2017b). In addition to selecting topics that a layperson likely recognizes (e.g., airports, weather, wildlife, safety), corpus-informed aviation dictionaries will help test developers identify words that flight training candidates are unlikely to know and make informed choices about how to handle these words in the texts (e.g., crafting items that do not require those words or glossing the words within the text). Judicious topic selection and vocabulary choices will help to balance the need for aviation content with the level of expected knowledge of the candidates.

\section{Conclusion}

In this article, the case for use of a screening assessment for flight training candidates in the United States was outlined. The FAA's evolving policy and guidance for English language proficiency assessment was discussed at some length to highlight the need to support AELS evaluators via a language proficiency screening assessment. The flight training domain was sketched out using emerging research as bolster to anecdote and intuition. Existing screening options were then assessed by the domain they are intended to be used for and the typical characteristics of such tests. Finding that none were a suitable match for the flight training domain, an existing aviation training screening test was evaluated. However, the need remains for a test that focuses only on the flight training context and addresses distinctive and consequential characteristics of flight training. A plan to develop such a test using a combination of domain expert collaboration, corpus linguistics, and text analysis was outlined.

The unfortunate outcome for student $\mathrm{X}$ mentioned in the beginning is not inevitable. A screening assessment can help identify candidates who need more language support before they even start their flight training; thus reducing the number of students who might otherwise struggle with slow progress or pose safety hazards during training. We hope that the increased attention on the impact of English proficiency on safe and efficient flight training will encourage US flight training and examining personnel to adopt such a test as a required admissions standard. In doing so, FTOs will be able to make decisions about whether a flight training candidate is ready to begin, whether they need aviation-specific English 
training, or whether they need foundational English training prior to aviation English. The proposed test may serve to begin standardizing aviation English testing in the US and guiding FTOs and their students to more targeted aviation English training.

\section{References}

AMERICAN COUNCIL ON THE TEACHING OF FOREIGN LANGUAGES (ACTFL). 2012.

ACTFL proficiency guidelines 2012. ACTFL. Available at:

$<$ https://www.actfl.org/sites/default/files/pdfs/public/ACTFLProficiencyGuidelines2012 FINAL.pdf. $>$. Access: 19 Jul 2020.

ALDERSON, J. C. 2010. A survey of aviation English tests. Language Testing, v. 27, n.1, pp. 51-72. doi:10.1177/0265532209347196

ALBRITTON, A. 2007. ICAO language ICAO language proficiency in proficiency in ab-initio flight training flight training. Paper presented at the ICAO Aviation Language Symposium. Available at: $<$ https://www.icao.int/Meetings/AMC/MA/Second\%20ICAO\%20Aviation\%20Language\%20Symposiu m\%20(IALS-2)/R1\%20Albritton.pdf> Access: 19 Jul 2020.

BACHMAN, L. F.; A. S. PALMER. 2010. Language Assessment in Practice. Oxford: Oxford University Press. 520 p.

BIBER, D. 2006. University language: a corpus-based study of spoken and written registers. Amsterdam; Philadelphia: J. Benjamins. 261 p.

BIBER, D.; CONRAD, S. M.; REPPEN, R.; BYRD, P.; HELT, M.; CLARK, V; CORTES, V.; CSOMAY, E.; URZUA, A. 2004. Representing Language Use in the University: Analysis of the TOEFL 2000 Spoken and Written Academic Language Corpus: Monograph Series. New Jersey:

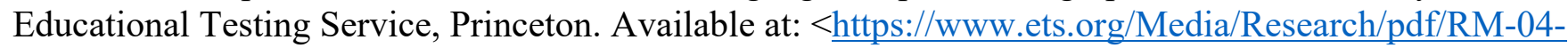
03.pdf>. Access: 19 Jul 2020.

BIBER, D.; S. CONRAD. 2009. Register, Genre, and Style. New York: Cambridge University Press, 2009.

BIESWANGER, M.; M. PRADO; J. ROBERTS. This volume. Ab initio pilot training and English as a lingua franca: some implications for the design of English for flight training courses.

CAMPBELL-LAIRD, K. 2006. Pedagogical approaches to aviation phraseology and communication training in collegiate flight programs. Collegiate Aviation Review International, 24.1: 25-41.

doi:10.22488/okstate.18.100341

CARR, N. 2011. Designing and analyzing language tests. Oxford: Oxford University Press. 360 p.

DUDLEY-EVANS, T.; M.J. ST. JOHN. 1998. Developments in English for Specific Purposes: a multidisciplinar approach. Cambridge: Cambridge University Press. 301 p.

DURRANT, P. 2014. Discipline and Level Specificity in University Students' Written Vocabulary. Applied Linguistics, 35.3: 328-356.

DUSENBURY, M.; E. BJERKE. 2013. Predictive power of English testing: Training international flight students. Journal of Aviation/Aerospace Education \& Research, 23.1: 13-22.

doi:10.15394/jaaer.2013.1601

EMERY, H. J. 2014. Developments in LSP testing 30 years on? the case of aviation English. Language Assessment Quarterly: Issues in Language Testing Revisited: Exam Board Perspectives and Future Directions, 11.2: 198-215. doi:10.1080/15434303.2014.894516 2016. Aviation English for the Next Generation. In: A. ENRIGHT; A. BOROWSKA (Orgs.). Changing Perspectives on Aviation English Training. Warsaw: University of Warsaw, p. 8-34. Available at:

$<$ https://portal.uw.edu.pl/documents/7732735/0/SN+29+A.+Borowska+A.+Enright+\%28ed.\%29\%20Ch anging+Perspectives + on+Aviation+English+Training.pdf $>$. Access: 19 Jul 2020. 
EMERY, H. J.; GLIDDON, D. 2019. ICAO Level 4 for Flight Training Admissions: A Square Peg in a Round Hole? (2019). International Civil Aviation English Association. 3. Available at:

$<$ https://commons.erau.edu/icaea-workshop/2019/day-2/3>. Access: 16 Sept 2020.

FEDERAL AVIATION ADMINISTRATION (FAA). 1997. English Language Skill Standards

Required by 14 CFR parts 61, 63, and 65. (Advisory Circular 60-28). Washington, D.C.: United States

Department of Transportation. Available

at: $<$ https://rgl.faa.gov/Regulatory_and_Guidance_Library/rgAdvisoryCircular.nsf/list/AC\%2060-

28/\$FILE/AC60-28.pdf>. Access: 19 Jul 2020.

FEDERAL AVIATION ADMINISTRATION (FAA). 2010. English Language Skill Standards

Required by 14 CFR parts 61, 63, and 65. (Advisory Circular 60-28 Change 1). Washington, D.C.: United States Department of Transportation. Available

at: $<$ https://www.faa.gov/documentLibrary/media/Advisory_Circular/AC_60-28_CHG.pdf $>$. Access: 19 Jul 2020.

FEDERAL AVIATION ADMINISTRATION (FAA). 2013. English Language Skill Standards Required by 14 CFR parts 61, 63, and 65. (Advisory Circular 60-28 A). Washington, D.C.: United States Department of Transportation. Available

at: $<$ https://www.faa.gov/documentLibrary/media/Advisory_Circular/AC_60-28A.pdf $>$. Access: 19

Jul 2020.

FEDERAL AVIATION ADMINISTRATION (FAA). 2016. FAA Student Pilot Guide (FAA-H-808327A). Washington, D.C.: United States Department of Transportation. Available

at: $<$ https://www.faa.gov/regulations_policies/handbooks_manuals/aviation/media/faa-h-8083-27a.pdf $>$. Access: 19 Jul 2020.

FEDERAL AVIATION ADMINISTRATION (FAA). 2017. FAA English Language Standard for an FAA Certificate Issued Under 14 CFR Parts 61, 63, 65, and 107 (Advisory Circular 60-28B).

Washington, D.C.: United States Department of Transportation. Available

at: $<$ https://www.faa.gov/documentlibrary/media/advisory_circular/ac_60-28b.pdf $>$. Access: 19

Jul 2020.

FEDERAL AVIATION ADMINISTRATION (FAA). 2020. FAI FSS - NOTAM overview. United

States Department of Transportation. Available

at: $<$ https://www.faa.gov/about/office org/headquarters offices/ato/service units/systemops/fs/alaskan/ alaska/fai/notam/ntm_overview/\#: : :text=A $\% 20$ Notice $\% 20$ To $\% 20$ Airmen $\% 20$ or,of $\% 20$ which $\% 20$ is $\% 2$ 0essential\%20to>. Access: 16 Sept 2020.

FLIGHT SAFETY FOUNDATION. 2000. FSF ALAR breifing note 1.4 - standard calls. Flight Safety

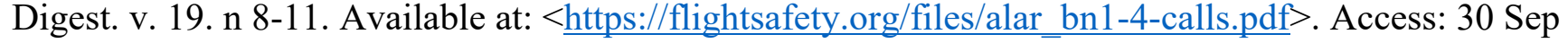
2020.

FRIGINAL, E.; E. MATHEWS; J. ROBERTS. 2020. English in Global Aviation. Great Britain: Bloomsbury. 320 p.

HOFFMAN, T. 2020. Aviation English, please. FAA Safety Briefing, 60.3: 28. Available at: <https://www.faa.gov/news/safety briefing/2020/media/MayJun2020.pdf > . Access: 30 Jul 2020. HYLAND, K. 2016. General and specific EAP. In: K. HYLAND; P. SHAW (Eds.). The Routledge Handbook of English for academic purposes. Routledge Handbooks in Applied Linguistics. London; New York: Routledge, p. 17-29.

HYLAND, K.; P. SHAW (Ed.). 2016. The Routledge Handbook of English for academic purposes. London; New York: Routledge. 646 p.

HYLAND, K.; P. TSE. 2007. Is There an “Academic Vocabulary"? TESOL Quarterly, 41.2: 235-253. INTERNATIONAL CIVIL AVIATION ENGLISH ASSOCIATION (ICAEA). 2011. Rated Speech Samples Developed for ICAO by ICAEA. ICAEA. Available at: $<$ https://cfapp.icao.int/rssta/RSS_Intro_V8.cfm>. Access: $30 \mathrm{Jul} 2020$. 
INTERNATIONAL CIVIL AVIATION ENGLISH ASSOCIATION (ICAEA). 2020. ICAO LPR test design guidelines. ICAEA. Available at: https://www.icaea.aero/icao-lpr-tdg/guidelines/. Access: 19 Jul 2020.

INTERNATIONAL CIVIL AVIATION ORGANIZATION (ICAO). 2001. Aeronautical Communications. Annex 10. Vol. II. (6th ed.). Montreal, Canada: International Civil Aviation Organization.

INTERNATIONAL CIVIL AVIATION ORGANIZATION (ICAO). 2010. Manual of implementation of the language proficiency requirements (Document 9835-AN/453) (2nd ed.). Montreal, Canada: International Civil Aviation Organization.

INTERNATIONAL CIVIL AVIATION ORGANIZATION (ICAO). 2016. Procedures for air navigation services - air traffic management. (Document 4444) (16th ed.). Montreal, Canada: International Civil Aviation Organization.

KIM, H. 2012. Exploring the construct of aviation communication: A critique of the ICAO language proficiency policy. Doctoral dissertation, Department of Linguistics and Applied Linguistics, University of Melbourne. Available at: <https://trove.nla.gov.au/work/168677972>. Access: 19 Jul 2020.

KNOCH, U.; S. MACQUEEN. 2020. Assessing language for professional purposes. New York: Routledge. $230 \mathrm{p}$.

LATITUDE. 2017a. Test development and maintenance. Checkpoint: Language Testing for Student Selection. Plymouth, UK: Latitude. Available at:

$<$ https://static1.squarespace.com/static/5742e4ef3c44d80a9c39295a/t/59109d928419c2fe3d0b7605/149 4261144585/Checkpoint+-+Test+development+-+May+2017.pdf $>$. Access: 19 Jul 2020.

LATITUDE. 2017b. Test reliability and validity. Checkpoint: Language Testing for Student Selection. Plymouth, UK: Latitude. Disponível em:

$<$ https://static1.squarespace.com/static/5742e4ef3c44d80a9c39295a/t/59115fa49de4bb22db4e2fec/1494 310827155/Checkpoint+-+Test+reliability+and+validity+-+May+2017.pdf $>$. Access: 19 Jul 2020.

LATITUDE. 2017c. Test structure, platform and scores. Checkpoint: Language Testing for Student Selection. Plymouth, UK: Latitude. Disponível em:

$<$ https://static1.squarespace.com/static/5742e4ef3c44d80a9c39295a/t/597b07dbf14aa19f19b1e18a/1501 235168330/Checkpoint+-+Test+platform\%2C+structure+and+scores+-+May+2017.pdf $>$. Access: 19 Jul 2020.

MATHEWS, E. 2001. Provisions for proficiency in common aviation language to be strengthened. ICAO Journal, 56.3: 24-26. Montréal.

MELL, J.; C. GODMET. 1997. Aeronautical Radiotelephony Communicative Functions. Direction de la Navigation Aerienne, DNA8 (F).

NEWBOLD, D. 2020. Rethinking English languages certification: new approaches to the assessment of English as an academic lingua franca. Venezia: Ca' Foscari. Available at: $<$ http://doi.org/10.14277/97888-6969-195-9/SAIL-12>. Access: 2 Oct 2020.

PHILPS, D. 1991. Linguistic security in the syntactic structures of air traffic control English. English World-Wide, 12.1: 103-124.

PRADO, M.; P. TOSQUI-LUCKS. 2019. Designing the Radiotelephony Plain English Corpus (RTPEC): A specialized spoken English language corpus towards a description of aeronautical communications in non-routine situations. Research in Corpus Linguistics, 7: 113-128.

ROBERTS, J.; A. ORR. 2020. Language education for ab initio flight training. Engaging the next generation of aviation professionals. In: S. K. KEARNS, T. J. MAVIN, S. HODGE (Orgs). Engaging the Next Generation of Aviation Professionals. London: Routledge. 1a ed. p. 149-162.

doi:10.4324/9780429287732-16. Available at:

$<$ https://www.taylorfrancis.com/books/e/9780429287732/chapters/10.4324/9780429287732-16>.

Access: 19 Jul 2020. 
SCARAMUCCI, M. V. R.; P. TOSQUI-LUCKS; S. M. DAMIÃO (Eds). 2018. Pesquisas sobre inglês aeronáutico no Brasil. Campinas: Pontes Editores. 313 p.

SWENDER, E.; R. VICARS. (Eds). 2012. ACTFL oral proficiency interview training manual.

Alexandria, VA: American Council on the Teaching of Foreign Languages.

TOSQUI-LUCKS, P.; A. L. B. C. SILVA. This volume. Aeronautical English: Investigating the nature of this specific language in search of new heights.

UDELL, R.; A. SCHNEIDER; Y. KIM. Forthcoming. Language proficiency for aviation training: A task-based needs analysis [manuscript in preparation].

WEIGLE, S. C.; M. E. MALONE. 2016. Assessment of English for academic purposes. In: K.

HYLAND; P. SHAW (Eds.). The Routledge Handbook of English for academic purposes. London; New York: Routledge. p. 608-619.

Jena Lynch holds a master's degree in Teaching English as a Second Language from Northern Arizona University (USA). Ms. Lynch is an Aviation English Specialist for Embry-Riddle Aeronautical University - Worldwide. She has taught Aviation English classes for the ERAU Flight Department and Language Institute. For ERAU's Aviation English Specialist team, Ms. Lynch specializes in online assessment, pedagogy, and materials development. In addition, she is an active member of the International Civil Aviation English Association (ICAEA).

Adriana Mendes Porcellato holds a PhD in Language Teaching from Universidade de São Paulo (USP) and a master's degree in Applied Linguistics from Universidade Federal de Minas Gerais (UFMG). In her studies, she has investigated the role of pragmatics and culture in foreign language teaching (Italian and English), with a specialfocus on the analysis and development of pedagogical material. Her investigation contributes to the work conducted by the research group "Pragmática (inter)linguística, cross-cultural e intercultural" at the Universidade de São Paulo, of which she is a member. 